\title{
STRATEGI PENGEMBANGAN AGRIBISNIS HASIL PERTANIAN MELALUI INOVASI DAN KREATIFITAS MENJADI PRODUK UNGGULAN DI SMK NEGERI 1 PACET KABUPATEN CIANJUR
}

\author{
Oleh: \\ IDA MARINA \\ Mahasiswa Pascasarjana Program Doktor Ilmu Pertanian Agribisnis \\ Fakultas Pertanian Universitas Padjajaran \\ Email: ida.marina19@yahoo.com
}

IRAMA YULISTIA

Guru Produktif, TPHP, SMK Negeri 1 Pacet-Cianjur.

\begin{abstract}
Abstrak
Penelitian ini mengenai strategi pengembangan agribisnis hasil pertanian melalui inovasi dan kreatifitas menjadi produk ; Pengembangan sektor agribisnis dapat menyesuaikan diri terhadap perubahan pasar, pengembangan sumberdaya agribisnis, khususnya pemanfaatan dan pengembangan teknologi serta pembangunan kemampuan Sumberdaya Manusia (SDM). Kendala yang di hadapi SMK Negeri 1 Pacet dalam mengembangkan agribisnis, belum didukung oleh agribisnis penunjang lain seperti pengadaan alat-alat produksi pengolahan hasil pertanian dan pengolahan agribisnis seperti industri pembuat kemasan. Strategi SMK Negeri 1 Pacet sudah menghasilkan out put yang diharapkan, dari lihat hasil analisis pada matrik SWOT diperoleh koordinat $(0.7 ; 1,475)$ yang mana koordinat ini pada kuadran I yaitu Strategi manajemen rotan, Strategi BUMI dan Strategi Pembelajaran Produktif. Strategi ini. Memiliki peluang dan kekuatan, sehingga dapat memanfaatkan peluang yang ada, strategi yang harus diterapkan adalah mendukung kebijakan dengan memanfaatkan peluang pengembangan komoditas unggulan.
\end{abstract}

Kata kunci: pengembangan strategi agribisnis -inovasi - kreativitas - produk unggulan

\section{PENDAHULUAN}

Isu strategis pembangunan ekonomi yang berkembang adalah pemberdayaan ekonomi rakyat yang notabene adalah dipedesaan. Pertumbuhan ekonomi yang tinggi belum tentu memihak pemberdayaan ekonomi rakyat. Kesejahteraan masyarakat merupakan komponen yang sangat penting dalam kemajuan suatu negara. Seiring dengan peningkatan kesejahteraan masyarakat maka peningkatan taraf hidup harus selalu di upayakan. Seperti halnya tujuan pembangunan nasional yang harus dicapai yaitu meningkatkan taraf hidup di daerah melalui pembangunan yang serasi, terpadu antar sektor perencanaan efisien dan efektif menuju tercapainya kesejahteraan rakyat.

Rendahnya kualitas sumberdaya manusia merupakan kendala yang serius dalam pembangunan pertanian. Mereka yang berpendidikan rendah pada umumnya adalah petani yang tinggal di daerah pedesaan, kondisi ini juga semakin menyulitkan dengan semakin berkurangnya upaya pendampingan dalam bentuk penyuluhan pertanian. Di sisi lain, bagi sebagian besar penduduk pedesaan, sudah kurang tertarik lagi bekerja dan berusaha di sektor pertanian, sehingga mengakibatkan semakin tingginya urbanisasi ke perkotaan. Kondisi ini hanya dapat ditekan dengan mengembangkan agroindustri pertanian di pedesaan, karena dapat membuka peluang keterlibatan seluruh pelaku, termasuk kelompok penduduk di pedesaan. Kelompok ini sesungguhnya dapat lebih memegang peranan penting dalam seluruh proses produksi usaha tani. Mereka berpeluang menjadi penyediaan dan distribusi sarana produksi, usaha jasa pelayanan alat dan mesin pertanian, usaha industri pasca panen dan pengolahan produk hasil pertanian, usaha jasa transportasi, pengelolaan lembaga keuangan mikro, sebagai konsultan manajemen agribisnis, serta tenaga pemasaran hasil-hasil produk agroindustri. Hal ini mengisyaratkan perlunya pembangunan pertanian dilakukan secara komprehensif dan terpadu dengan pengembangan sektor komplemennya (agroindustri, penyediaan kredit, teknologi melalui penyuluhan, dan pasar), sehingga menghasilkan nilai tambah di luar lahan dan upah tenaga fisiknya. 


\section{AIMBAR \\ Agribisnis}

ISSN 2460-4321

Volume 1・Nomor 1・Juli 2015

Mubyarto dalam Kasrino (1996) mengemukakan bahwa secara nasional rasio pendapatan kota dan desa selama tahun 19831993 semakin mengalami peningkatan dari 1,69 tahun 1981 menjadi 1,82 tahun 1993. Artinya laju pertumbuhan pendapatan perkotaan jauh lebih cepat bila dibandingkan dengan laju pertumbuhan pendapatan dipedesaan. Akibat yang timbul menguatnya arus urbanisasi dan migrasi penduduk dari pedesaan ke perkotaan, sehingga menjadi persoalan bagi pembangunan dipedesaan karena pelarian sumberdaya manusia dan kapital yang bila berlangsung terus menerus dikhawatirkan semakin memperbesar kesenjangan ekonomi dan pembangunan.

Untuk mengurangi ketimpangan tersebut, diperlukan pengembangan sektor ekonomi yang mampu mengintegrasikan perekonomian antara usaha tani dan industri/jasa, artinya dipedesaan perlu dikembangkan pengelolaan usahatani yang berbasisis spesifik lokasi dan berorentasi pada kegiatan produksi, pengolahan dan pemasaran (agribisnis).

Komoditas agribisnis terbesar Indonesia salah satunya berada di provinsi Jawa Barat. Secara umum provinsi ini memiliki potensi yang besar dan variatif serta di dukung oleh agroekosistem yang cocok untuk pengembangan komoditas pertanian khususnya hortikultura. Sektor pertanian juga memiliki tingkat penyerapan tenaga kerja yang tinggi yaitu rata-rata sebesar 29,65 \% dari jumlah penduduk bekerja, namun hubungan antar sub sistem pertanian dan sektor lain belum sepenuhnya menunjukkan sinergitas pada skala lokal, regional dan nasional, hal ini tercermin dari pengembangan agro industri yang belum optimal dalam pengolahan dan pemasarannya

Pusat pertanian Jawa barat salah satu terkonsentrasi di wilayah Kabupaten Cianjur. Kondisi pertanian Kabupaten Cianjur dilihat dari aspek fisiknya yaitu beriklim tropis dengan curah hujan per tahun rata-rata 1000 sampai $4000 \mathrm{~mm}$ dan jumlah hari hujan rata-rata 150 per tahun. Dengan iklim tropis tersebut menjadikan kondisi alam Kabupaten Cianajur subur dan mengandung keanekaragaman kekayaan sumber daya alam yang potensial sebagai modal dasar pembangunan dan potensi investasi yang menjanjikan. Lahan lahan pertanian tanaman pangan dan hortikultura, perikanan dan perkebunan merupkan sumber kehdupan bagi masyarakat.

Mata Pencaharian Penduduk Kabupaten Cianjur sektor pertanian yaitu sekitar 62,99\%. Sektor pertanian merupakan penyumbang terbesar terhadap produk domestik regional bruto (PDRB) yaitu sekitar $42,80 \%$, berbagai pertimbangan geografis, letak geologis dan klimatologis serta sosio-kulturnya yang beragam tersebut sangat penting di kaji dalam mengelola sumber daya wilayah untuk kesejahteraan penduduk khususnya petani. Dengan pendekatan sistem dan usaha agribisnis tersebut, maka pembangunan pertanian jelas berbasis pada rakyat dan berkelanjutannya akan terjamin dengan sendirinya karena pengembangannya memanfaatkan sumberdaya lokal. Pendekatan pembangunan yang berasal dari rakyat dilaksanakan oleh rakyat dan dimanfaatkan sebesar-besarnya untuk kemakmuran dan keadilan seluruh rakyat Indonesia, merupakan tantangan yang berpeluang menang dalam menghadapi persaingan global yang semakin ketat dan tajam.

Kabupaten Cianjur perlu didukung sepenuhnya dalam peningkatan produktivitas pertanian. Karena Cianjur memiliki potensi yang besar untuk mengembangkan pertanian serta akan mampu menjadi contoh untuk daerah lain di Indonesia. Demikian ditegaskan oleh Staf Ahli Menteri Bidang Investasi Pertanian, Prabowo Respatiyo Caturroso saat berkunjung ke Cianjur, Selasa (13/11/2012)

Meningkatkan produktifitas pertanian memerlukan sinergi dan kerjasama serta koordinasi yang kuat, konsisten dan berkesinambungan antara pemerintah, pengusaha dan para aktivis bidang pertanian dengan fokus pada peningkatan penguasaan terhadap sumber daya manusia dan teknologi pertanian sehingga hasil-hasil pertanian bisa memilki nilai ekonomi yang tinggi yang dapat mensejahterakan para petani.

Lahan pertanian di Kabupaten Cianjur masih sangat luas dan memiliki potensi serta prospek yang cerah di masa mendatang, akan tetapi pendanaan daerah masih kurang memadai untuk membiayai garapan bidang pertanian secara maksimal. Pengembangan agroindustri berbasis kemitraan petani diharapkan melahirkan pelaku pertanian yang profesional, 


\section{Strategi Pengembangan Agribisnis Hasil Pertanian Melalui Inovasi dan Kreatifitas Menjadi Produk Unggulan di SMK Negeri 1 Pacet Kabupaten Cianjur \\ IDA MARINA DAN IRAMA YULISTIA}

beretos kerja industrial dan bervisi kepentingan nasional. Pengembangan agroindustri terpadu dan berkelanjutan diperlukan untuk meningkatkan produksi, nilai tambah dan daya saing komoditas pertanian guna mewujudkan kemandirian pangan

Produk unggulan merupakan produk yang potensi untuk dikembangkan dalam suatu wilayah dengan memanfaatkan sumber daya alam dan sumber daya manusia setempat. Serta mendatangkan pendapatan bagi masyarakat maupun pemerintah. Produk unggulan harus memiliki daya saing berorientasi pasar, ramah lingkunganm, sehingga tercipta keunggulan kompetitif yang siap menghadapi pasar global

Menjalankan suatu usaha atau bisnis menjadi suatu produk unggulan salah satu kunci suksesnya adalah inovasi dan kreativitas suatu produk dalam memenangkan pasar. Dengan menciptakan produk baru yang berbeda dengan produk lainnya, bisnis Anda memiliki nilai lebih dibandingkan dengan bisnis lainnya. Tentunya sangat penting mendorong kreativitas dan menjadi benar-benar inovatif. Inovasi tercipta karena adanya kreativitas yang tinggi. Kreativitas adalah kemampuan untuk membawa sesuatu yang baru ke dalam kehidupan.

SMK Negeri 1 Pacet merupakan sekolah kejuruan yang memiliki jurusan pertanian yang sudah mengembangkan kegiatan agribisnis pertanian mulai dari hulu ke hilir, penulis ingin mengetahui strategi apa yang digunakan untuk pengembangan kegiatan agribisnis (Pengolahan hasil pertanian/ Agro Industri) melalui inovasi dan kreativitas yang akan menghasilkan produk unggulan dari SMK Negeri 1 Pacet dengan melihat factor eksternal dan internal dari sekolah tersebut.

Kekuatan dan Kelemahan Internal SMK Negeri 1 Pacet.

\section{Kekuatan}

a. Terdapatnya potensi sumber daya alam yang cukup besar

b. Tersedianya guru sukarelawan sekolah

c. Terdapatnya sarana belajar pendukung

d. Meningkatnya motivasi masyarakat akan peduli pendidikan

e. Letak geofrafis yang strategis antara Ibu Kota Propinsi dan Ibu Kota Negara

f. Kondisi politik dan keamanan yang stabil

2. Kelemahan

a. Terbatasnya alokasi dana pendidikan dari APBD (Pemda Propinsi dan Kabupaten) b. Penyebaran guru kurang merata

c. Belum optimalnya penggunaan sarana pendukung

d. Aspirasi masyarakat secara umum belum terwadahi

e. Profesionalisme tenaga kependidikan pada umumnya masih rendah

f. Kemampuan manajerial disemua jenjang masih rendah

g. Pemanfaatan lulusan lembaga pendidikan terhadap dunia usaha belum optimal.

Kekuatan dan Tantangan Eksternal SMK Negeri 1 Pacet

1. Kekuatan

a. Latar belakang para guru sebagian besar sarjana

b. Kesiapan sekolah untuk melaksanakan KBK

c. Adanya konsep dan pelaksanaan pendidikan sistem ganda

d. Adanya mutu pendidikan dengan standar nasional

e. Adanya peserta yang mengikuti olympiade mata pelajaran dan LKS tingkat propinsi dan nasional

2. Kelemahan

a. Ketidaksesuaian antara kompetensi guru dengan bidang studi yang menjadi tugasnya

b. Masih kurangnya tenaga fungsional yang mengembangkan silabus KBK

c. Lemahnya dukungan dari DU/ DI dengan standar kompetensi nasional

Berdasarkan uraian di atas, maka dapat dirumuskan beberapa permasalahan penelitian yaitu sebagai berikut :

1. Bagaimana strategi pengembangan kegiatan agribisnis yang ada di SMK Negeri 1 Pacet?

2. Bagaimana inovasi dan kreatifitas produk yang dihasilkan dari kegiatan agribisnis di SMK Negeri 1 Pacet?

3. Apa saja produk- produk unggulan yang dihasilkan dari kegiatan agribisnis di SMK Negeri 1 Pacet?

Tujuan penelitian ini untuk mengetahui strategi yang di gunakan untuk mengembangkan kegiatan agribisnis, kendalakendala, output dan inovasi serta kreatifitas produk yang telah dihasilkan dalam kegiatan agribisnis yang telah dijalankan di SMK Negeri 1 Pacet. 


\section{MIMBAR \\ A GRIBISNIS $_{\text {G }}$ \\ ISSN 2460-4321}

Volume $1 ・$ Nomor $1 ・$ Juli 2015

\section{METODE PENELITIAN}

Metode yang digunakan dalam penelitian ini adalah studi kasus di SMK Negeri 1 Pacet Kecamatan Pacet Kabupaten Cianjur. Sebagai subyek atau satuan analisis penelitian ini adalah sekolah dan obyek penelitiannya adalah variable pokok penelitian faktor strategi pengembangan kegiatan bisnis, inovasi dan kreatifitas dalam kegiatan agribisnis serta hasil produk dalam kegiatan agribisnis yang akan di jadikan produk unggulan .

\section{HASIL DAN PEMBAHASAN}

Pengembangan Kegiatan Agribisnis Yang Ada di SMK Negeri 1 Pacet

SMK Negeri 1 Pacet memandang Agribisnis itu adalah suatu sistem yang utuh mulai sub-sistem penyediaan sarana produksi dan peralatan pertanian; sub-sistem usahatani; sub-sistem pengolahan atau agroindustri dan sub-sistem pemasaran. Agar sub-sistem ini bekerja dengan baik maka diperlukan dukungan sub-sistem kelembagaan sarana dan prasarana serta sub-sistem penunjang dan pembinaan. Agribisnis sebagai suatu sistem adalah agribisnis merupakan seperangkat unsur yang secara teratur saling berkaitan sehingga membentuk suatu totalitas. Disini dapat diartikan bahwa agribisnis terdiri dari dari berbagai sub sistem yang tergabung dalam rangkaian interaksi dan interpedensi secara reguler, serta terorganisir sebagai suatu totalitas.

Kegiatan Agribisnis di SMK Negri 1 Pacet itu adalah dilakukan oleh siswa dan guru, dimana siswa di libatkan dalam kegiatan pembelajaran yaitu produksi, pemasaran , sedangkan duru dilibatkan dalam penentuan kualitas dari hasil produksi dan pemantauan kegiatan pemasaran, sedangkan dunia industri/ dunia usaha itu memantau kelayakan dari produk yang dibuat atau di produksi oleh jurusan Teknologi Pengolahan Hasil Pertanian sebagai hasil karya inovatif dan kreatif dari kegiatan agribisnis sehingga akan menghasilkan suatu produk baru yang dapat dijadikan produk unggulan.

Adapun kelima mata rantai atau subsistem tersebut dapat diuraikan sebagai berikut:

1. Subsistem Penyediaan Sarana Produksi

SMK Negeri 1 Pacet dalam penyediaan sarana produksi menyangkut kegiatan pengadaan dan penyaluran. Kegiatan ini mencakup Perencanaan, pengelolaan dari sarana produksi, teknologi dan sumberdaya agar penyediaan sarana produksi atau input usahatani memenuhi kriteria tepat waktu, tepat jumlah, tepat jenis, tepat mutu dan tepat produk.

2. Subsistem Usahatani atau proses produksi

SMK Negeri 1 Pacet menjalankan usaha ini mencakup kegiatan pembinaan dan pengembangan usahatani dalam rangka meningkatkan produksi primer pertanian. Termasuk kedalam kegiatan ini adalah perencanaan pemilihan lokasi, komoditas, teknologi, dan pola usahatani dalam rangka meningkatkan produksi primer. Disini ditekankan pada usahatani yang intensif dan sustainable (lestari), artinya meningkatkan produktivitas lahan semaksimal mungkin dengan cara intensifikasi tanpa meninggalkan kaidah-kaidah pelestarian sumber daya alam yaitu tanah dan air. Disamping itu juga ditekankan usahatani yang berbentuk komersial bukan usahatani yang subsistem, artinya produksi primer yang akan dihasilkan diarahkan untuk memenuhi kebutuhan pasar dalam artian ekonomi terbuka.

3. Subsistem Agroindustri/pengolahan hasil

Di SMK negeri 1 Pacet lingkup kegiatan ini tidak hanya aktivitas pengolahan sederhana di tingkat pelajar, tetapi menyangkut keseluruhan kegiatan mulai dari penanganan pasca panen produk pertanian sampai pada tingkat pengolahan lanjutan dengan maksud untuk menambah value added (nilai tambah) dari produksi primer tersebut. Sehingga barang hasil produksi bias menjadi produk unggulan dari sekolah ,ataupun bias menjadi unggulan untuk daerah setempat.

\section{Subsistem Pemasaran}

SMK negeri 1 Pacet sub sistem pemasaran mencakup pemasaran hasil-hasil usahatani dan agroindustri baik untuk pasar local Cianjur maupun ke beberapa daerah di Indonesia. Kegiatan utama subsistem ini adalah pemantauan dan pengembangan informasi pasar dan market intelligence pada pasar pasar lokal Cianjur maupun ke beberapa daerah di Indonesia. 


\section{Strategi Pengembangan Agribisnis Hasil Pertanian Melalui Inovasi dan Kreatifitas Menjadi Produk Unggulan di SMK Negeri 1 Pacet Kabupaten Cianjur}

IDA MARINA DAN IRAMA YULISTIA

5. Subsistem Penunjang

Subsistem yang dilakukan SMK Negeri 1 Pacet ini merupakan penunjang kegiatan pra panen dan pasca panen yang meliputi:

a. Sarana Tataniaga

b. Penyuluhan Agribisnis

c. Infrastruktur agribisnis

d. Koperasi Agribisnis

e. Swasta

f. Penelitian dan Pengembangan

g. Pendidikan dan Pelatihan

h. Kebijakan Pemerintah

SMK Negeri 1 Pacet dalam menggerakkan Sistem agribisnis mendapat dukungan dari semua pihak yang berkaitan dengan agribisnis/ pelaku-pelaku agribisnis mulai dari Pelajar, guru, orang tua siswa, Dunia industri dan dunia usaha , Koperasi, BUMN dan swasta, peneliti serta seorang Dirigent yang mengkoordinasi keharmonisan Sistem Agribisnis.

\section{Pengembangan Sumberdaya Agribisnis}

SMK Negeri 1 Pacet dalam pengembangan sektor agribisnis dapat menyesuaikan diri terhadap perubahan pasar, pengembangan sumberdaya agribisnis, khususnya pemanfaatan dan pengembangan teknologi serta pembangunan kemampuan Sumberdaya Manusia (SDM) Agribisnis sebagai aktor pengembangan agribisnis. SMK Negeri 1 Pacet melakukan kerjasama pembangunan kemampuan Sumberdaya Manusia (SDM) baik guru maupun siswa dengan intansi pemerintah dan swasta melalui pelatihan baik dilakukan secara formal maupun informal.

\section{Pengembangan Pusat Pertumbuhan Sektor Agribisnis.}

SMK Negeri 1 Pacet melakukan pengembangan agribisnis dipusatkan pada pertumbuhan sektor agribisnis komoditas unggulan yang didasarkan pada peta perkembangan komoditas agribisnis, potensi perkembangan dan kawasan kerjasama ekonomi dengan steakholder.

\section{Pengembangan Infrastruktur Agribisnis.}

SMK Negeri 1 Pacet dalam pengembangan pusat pertumbuhan Agribisnis tengah di dukung oleh pengembangan Infrastruktur seperti jaringan jalan dan transportasi (laut, darat, sungai dan udara), jaringan listrik yang harus terpenuhi , air yang harus memadai , sarana prasarana yang sesuai dengan standart operasional prosedur dari industri atau laboratorium dan lain-lain.

Kebijaksanaan terpadu pengembangan

Di SMK Negeri 1 Pacet Ada beberapa bentuk kebijaksanaan terpadu dalam pengembangan agribisnis.

a. Kebijaksanaan pengembangan produksi dan produktivitas ditingkat perusahaan tetapi tidak menghilangkan peran pembelajaran pada kegiatan tersebut untuk siswa SMK Negeri 1 Pacet

b. Kebijaksanaan tingkat sektoral untuk mengembangkan seluruh kegiatan usaha sejenis .

c. Kebijaksanaan pada tingkat sistem agribisnis yang mengatur keterkaitan antara beberapa sektor.

d. Kebijaksanaan ekonomi makro yang mengatur seluruh kegiatan perekonomian yang berpengaruh langsung maupun tidak langsung terhadap agribisnis.

\section{Pengembangan agribisnis berskala kecil.}

SMK Negeri 1 Pacet merupakan pengembangan agribisnis berskala kecil, Ada 3 kebijaksanaan yang dilakukan adalah:

\section{a. Farming Reorganization}

Reorganisasi jenis kegiatan usaha yang produktif dan diversifikasi usaha yang menyertakan komoditas yang bernilai tinggi serta reorganisasi manajemen terkait dengan proses pembelajaran siswa dan guru sebagai pembimbing. Dalam hal ini disebabkan karena keterbatasan sumber daya manusia dan lahan yang di gunakan untuk kegiatan agribisnis tersebut.

b. Small-scale Industrial Modernization

Modernisasi teknologi, modernisasi sistem, organisasi dan manajemen, serta modernisasi dalam pola hubungan dan orientasi pasar.

c. Services Rasionalization

Pengembangan layanan agribisnis dengan rasionalisasi lembaga penunjang kegiatan agribisnis untuk menuju pada efisiensi dan daya saing lembaga tersebut. Terutama adalah lembaga keuangan, lembaga litbang khususnya penyuluhan dan pelatihan. 


\section{AIMBAR \\ Agribisnis}

ISSN 2460-4321

Volume 1・Nomor 1・Juli 2015

Pembinaan Sumberdaya Manusia Untuk Mendukung Pengembangan Agribisnis Dan Ekonomi

SMK Negeri 1 Pacet dalam era Agribisnis, aktor utama pembangunan agribisnis yaitu guru dan siswa dan aktor pendukung pembangunan agribisnis (Dunia Industri / Dunia Usaha) dilakukan melalui pembinaan kemampuan aspek bisnis, manajerial dan berorganisasi bisnis dalam pembelajaran serta peningkatan wawasan agribisnis. Dalam hal ini di reorientasikan peran penyuluhan pertanian yang merupakan lembaga pembinaan SDM pelajar. Oleh karena itu dipeningkatan pendidikan penyuluh baik melalui pendidikan formal, kursus singkat, studi banding. Serta melalui perubahan fungsi BPP yang selama ini sebagai lembaga penyuluhan agro-teknis, yang dilibatkan menjadi Klinik Konsultasi Agribisnis.

Analisis SWOT ditujukan untuk mengidentifikasi berbagai faktor untuk merumuskan strategi. Analisis ini didasarkan pada usaha untuk memaksimalkan kekuatan dan peluang, namun dapat meminimalkan kelemahan dan ancaman secara bersama.

Tabel 1. Faktor Internal Strategi Pengembangan Agribisnis SMK 1 Pacet

\begin{tabular}{|c|c|c|c|}
\hline Unsur & Bobot & Rating & Skor \\
\hline \multicolumn{4}{|l|}{ Kekuatan } \\
\hline Statragi Rotan & 0,15 & 4 & 0,60 \\
\hline Strategi Bumi & 0,15 & 4 & 0,60 \\
\hline $\begin{array}{l}\text { Strategi } \\
\text { Pembelajaran } \\
\text { Produktif }\end{array}$ & 0,11 & 3 & 0,60 \\
\hline $\begin{array}{l}\text { Sub Total } \\
\text { Kekuatan }\end{array}$ & 0,41 & & 1,80 \\
\hline \multicolumn{4}{|l|}{ Kelemahan } \\
\hline Keuangan & 0,15 & -1 & $-0,15$ \\
\hline $\begin{array}{l}\text { Penyediaan } \\
\text { Sarana } \\
\text { Penunjang }\end{array}$ & 0,15 & -3 & $-0,45$ \\
\hline Managerial & 0,07 & -2 & $-0,14$ \\
\hline Teknologi & 0,11 & -2 & $-0,22$ \\
\hline Calon siswa & 0,11 & -2 & $-0,22$ \\
\hline \multirow[t]{2}{*}{$\begin{array}{l}\text { Sub Total } \\
\text { Kelemahan }\end{array}$} & 0,59 & & $-1,18$ \\
\hline & 1 & & 0,62 \\
\hline
\end{tabular}

SMK Negeri 1 Pacet memiliki ancamaancaman sebagai faktor eksternal yang akan timbul atau muncul harus ditekan karena akan mempengaruhi dalam kemajuan kegiatan agribisnis dan proses pembelajaran di sekolah, untuk lebih jelas faktoe eksternal dapat dilihat pada tabel 2.

Tabel 2. Faktor Eksternal Pengembangan Agribisnis SMK 1 Pacet

\begin{tabular}{|l|c|c|c|}
\hline \multicolumn{1}{|c|}{ Unsur } & Bobot & Rating & Skor \\
\hline Kekuatan & 0,15 & 4 & 0,60 \\
\hline $\begin{array}{l}\text { Permintaan Pasar } \\
\text { Meningkat }\end{array}$ & 0,15 & 4 & 0,60 \\
\hline $\begin{array}{l}\text { Permintaan untuk } \\
\text { Pelatihan }\end{array}$ & 0,11 & 3 & 0,33 \\
\hline Produk Unggulan & 0,15 & 2 & 0,30 \\
\hline $\begin{array}{l}\text { Penempatan } \\
\text { lulusan }\end{array}$ & 0,63 & 2 & 0,14 \\
\hline $\begin{array}{l}\text { Wisata } \\
\text { pendidikan }\end{array}$ & 0,15 & -3 & $-0,45$ \\
\hline $\begin{array}{l}\text { Sub Total } \\
\text { Kekuatan }\end{array}$ & 0,15 & -4 & $-0,60$ \\
\hline Ancaman & 1 & -2 & $-0,14$ \\
\hline Pesaing & 0,07 & & $-1,19$ \\
\hline $\begin{array}{l}\text { Ketercapaian } \\
\text { target produk }\end{array}$ & 0,37 & 0,78 \\
\hline Opini masyarakat
\end{tabular}

Analisis SWOT ditunjukkan untuk mengidentifikasi berbagai factor untuk merumuskan strategi berdasarkan data faktorfaktor internal dan eksternal diperoleh skor pembobotan sebagai berikut :

Faktor kekuatan $\quad=0,41$

Factor kelemahan $\quad=0,59$

Faktor peluang $\quad=0,63$

Factor ancaman $\quad=0,37$

Dari skor pembobotan diatas selanjutnya diplotkan pada gambar analisis diagram sebagai berikut :

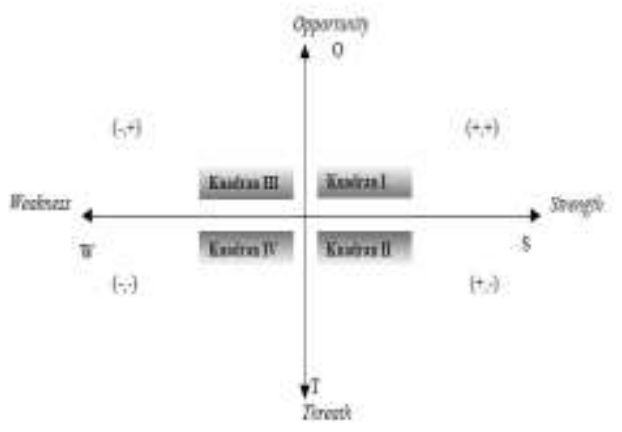

Gambar 1. Matriks kuadran SWOT 


\section{Strategi Pengembangan Agribisnis Hasil Pertanian Melalui Inovasi dan Kreatifitas Menjadi Produk Unggulan di SMK Negeri 1 Pacet Kabupaten Cianjur \\ IDA MARINA DAN IRAMA YULISTIA}

Dari perpotongan keempat garis faktor kekuatan, kelemahan, peluang dan ancaman, maka diperoleh koordinat $(-0.9 ; 0,13)$.

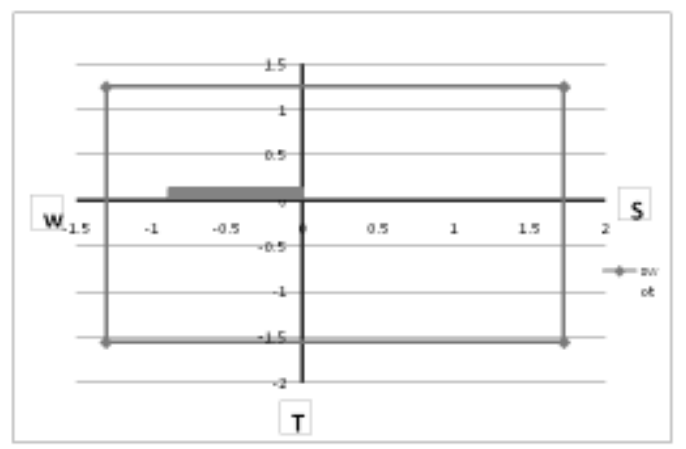

Gambar 2. Titik Posisi Analisis SWOT

Analisa SWOT yang dilakukan dapat digunakan sebagai dasar dalam penentuan strategi pengembangan agribisnis hasil pertanian SWOT matrik ini dibangun berdasarkan hasil analisis faktor-faktor strategis baik internal maupun eksternal yang terdiri dari faktor kekuatan, kelemahan, peluang dan ancaman. Hasil analisis pada matrik SWOT diperoleh koordinat $(-, 09 ; 0,13)$ yang mana koordinat ini pada kuadran III yaitu trunaraund. Posisi ini menunjukan peluang pasar yang sangat besar, tetapi dilain pihak, menghadapi beberapa kendala /kelemahan internal. Kondisi bisnis pada kuadran ini mirip dengan Qeustion Mark pada BCG matrik. Fokus strategi perusahaan ini adalah meminimalkan masalah-masalah internal perusahaan sehingga dapat merebut peluang pasar yang lebih baik; artinya SMK 1 Pacet harus lebih membenahi masalah keuangan unit produksi, meningkatkan sarana penunjang salah satunya peralatan produksi, uji mutu dan pengemasan. Manajemen SMK 1 Pacet perlu adanya pembenahan sesuai dengan tugas dan fungsi (job deckription). Penerapan teknologi baik dari aspek pembelajaran maupun inovasi produk lebih memperhatikan permintaan dari konsumen dapat dilakukan melalui disversifikasi prodak dan peningkatan mutu atau kualitas produk sehingga saran dan tujuan dari SMK 1 Pacet untuk mewujudkan produk unggulan dapat tercapai dengan baik.

Pemecahan dan Alternatif Pemecahan yang harus di perhatikan, agar kegiatan agribisnis dan kegiatan pembelajaran menjadi lebih maju dan lebih baik lagi sehingga akan menghasilkan lulusan yang produktif kreatif dan inovatif.

1. Perluasan kesempatan dan pemerataan pendidikan

a. Menggalang partisipasi masyarakat untuk ikut serta dalam pembangunan pendidikan

b. Bantuan dana untuk kegiatan peningkatan kompetensi guru-guru perlu diprogramkan

c. Adanya relevansi sarana pendukung pendidikan (sarana prasarana lebih optimal/ memadai sesuai dengan standard operasional prosedur)

d. Penyaluran aspirasi masyarakat peduli pendidikan melalui wadah komite sekolah

2. Peningkatan mutu relevansi pendidikan

a. Melaksanakan tes kompetensi guru dan pelatihan kompetensi guru secara terpadu

b. Melaksanakan work shop guru mata pelajaran yang relevan dengan kurikulum 2013

c. Memberdayakan Majelis Pendidikan Kejuruan Daerah (MPKD) untuk menjalin koordinasi yang efektif dengan DU (Dunia Usaha)/ DI (Dunia Industri).

3. Efisiensi peningkatan manajemen pendidikan

a. Menggalang partisipasi Dana Sumbangan Pendidikan (DSP) untuk pengembangan Sistem Pembinaan Profesional (SPP)

b. Menggalang partisipasi untuk pemberdayaan wadah-wadah profesi Musyawarah Kerja Kepala sekolah, Musyawarah Guru Mata Pelajaran, dan MKPS

c. Melaksanakan sosialisasi tugas dan fungsi komite sekolah

4. Pengembangan manajemen dan pembinaan lingkungan.

5. Peningkatan sumber daya dan unit produksi menjadi produk unggulan sekolah dan daerah setempat.

6. Pembinaan ketenagaan.

7. Pengembangan proses belajar mengajar.

8. Pembinaan kesiswaan secara menyeluruh agar menjadi siswa yang kreatif dan inovatif.

9. Pengembangan fasilitas (sarana Prasarana). 


\section{MIMBAR \\ A GRIBISNIS \\ ISSN 2460-4321}

Volume 1・ Nomor 1・Juli 2015

10.Pembinaan hubungan masyarakat dan Dunia Usaha/ Dunia Industri

\section{PENUTUP}

\section{Simpulan}

Berdasarkan hasil analisis faktor-faktor strategis baik internal maupun eksternal Strategi pengembangan kegiatan agribisnis yang ada di SMK Negeri 1 Pacet yang terdiri dari faktor kekuatan, kelemahan, peluang dan ancaman. Hasil analisis pada matrik SWOT diperoleh koordinat $(-, 09 ; 0,13)$, artinya SMK 1 Pacet harus lebih membenahi masalah keuangan unit produksi, meningkatkan sarana penunjang salah satunya peralatan produksi, uji mutu dan pengemasan. Manajemen SMK 1 Pacet perlu adanya pembenahan sesuai dengan tugas dan fungsi (job deckription). Penerapan teknologi baik dari aspek pembelajaran maupun inovasi produk lebih memperhatikan permintaan dari konsumen dapat dilakukan melalui disversifikasi prodak dan peningkatan mutu atau kualitas produk sehingga saran dan tujuan dari SMK 1 Pacet untuk mewujudkan produk unggulan daapat tercapai dengan baik.

Inovasi dan kreatifitas produk yang dihasilkan dari kegiatan agribisnis di SMK Negeri 1 Pacet yaitu dengan menciptakan suatu produk menggunakan bahan baku dari sumber daya alam yang tersedia di lingkungan dengan memanfaatkan kearifan lokal yang ada.

Produk-produk unggulan yang dihasilkan dari kegiatan agribisnis di SMK Negeri 1 Pacet adalah berupa aneka keripik (krupuk daun singkong rasa paru, kripik daun wortel, kerupuk daun lokat mala, kerupuk daun kemangi, kerupuk daun bayam, kerupuk daun katuk serta berbagai stik dan abon) dengan bahan dasar daun-daunan yang selama ini belum termanfaatkan dangan baik dapat dijdikan suatu produk unggulan.

\section{Saran}

Penarapan strategi yang di terapkan SMK 1 Pacet lebih ditingkatkan dan penerapannya secara menyeluruh oleh setiap bagian yang terlibat di dalamnya agar apa yang menjadi capaian dapat terwujud dengan baik.

SMK 1 Pacet seharusnya sudah memikirkan alat pendukung agribisnis seperti pengadaan alat-alat produksi pengolahan hasil pertanian dan pengolahan agribisnis seperti industri pembuat kemasan.

SMK 1 Pacet dalam peningkatan Output/ produk sebaiknya lebih menginformasikan strategi pengembangan prodak unggulan kepada setiap bagian yang ada di SMK 1 Pacet dan lebih memperluas lagi jaringan sosialisasi kepada masyarakat luar dengan berbagai media sosialisasi untuk lebih dikenal dan diaplikasikan.

\section{Ucapan Terima Kasih}

Tak terlupa pula kepada SMK 1 Pacet yang telah memberikan kesempatan untuk melaksanakan penelitian ini. Tanpa dukungan SMK 1 Pacet karya ini tidak akan lahir.

Serta pendorong untuk mengeksplorasi inspirasi dan gagasan dalam penelitian ini, tak terlepas Support dari keluarga besar, ayah ibu serta mertuaku yang memberi waktu luang untuk melaksanakan penelitian ini, berkat doa dan bingbingannya pula jalanku terarah. Terimakasih untuk suamiku yang telah sabar mendampingi serta memberikan motivasi pada setiap proses penelitian, semoga mereka ada dalam lindungan ilahi dan selalu sabar untuk menghadapi hidup untuk ibadah kepada Alloh Swt

Yang terakhir, terimakasih pada orangorang yang tidak saya sebutkan satu-persatu yang telah mendukung dalam penelitian ini dan mudah-mudahan penelitian ini menjadi dasar untuk penelitian kedepannya.

\section{DAFTAR PUSTAKA}

Arikunto. 2002. Prosedur Penelitian Suatu Praktek. RinekaCipta. Jakarta.

Buletin. 1977. Vitamin C. Merck Service Buletin. Merck and Co. Inc. New Jersey.

DepartemenPertanian. 2007-2008. Hortikultura. Produksi Tanaman Sayuran Indonesia. Jakarta.

http://www.hortikultura.deptan.go.id.(7 Mei 2013).

Dinas Pertanian Tanaman Pangan dan Hortikultura, 2011. Agribisnis Teori dan Aplikasinya. Artikel online dari http://id.shvoong.com/internet-andtechnologies/business-economy/ 1854032agribisnis-teori-dan-aplikasinyaagribusiness/\#ixzz1f1WmTS1w 


\section{Strategi Pengembangan Agribisnis Hasil Pertanian Melalui Inovasi dan Kreatifitas Menjadi Produk Unggulan di SMK Negeri 1 Pacet Kabupaten Cianjur \\ IDA MARINA DAN IRAMA YULISTIA}

Gujarati. 1993. Ilmu Usaha Tani. Penebar Swadaya, Jakarta.

Hafsah, Muhammad Jafar, 1999. Kemitraan Usaha. Jakarta. Pustaka Sinar Harapan.

Hadisapoetra, S. 1983. Biayadan Pendapatan di Dalam Usahatani. Departemen Ekonomi Pertanian, Universitas Gadjah Mada. Yogyakarta.

Hernanto, F. 1996. Ilmu Usaha Tani, Penebar Swadaya, Jakarta.

Hermawan, R. Membangun Sistem Agribisnis. Artikel online. Makalah Seminar Mahasiswa.tgl.20 Desember 2006. Faperta UGM Yogyakarta.

Institut Pertanian Bogor, 2004. Pengembangan Agropolitan Sebagai Strategi Pembangunan Desa dan Wilayah Secara Berimbang. Pusat Pengkajian Perencanaan dan Pengembangan Wilayah IPB dan Penataan Pengembangan DesaTerpadu (P4W - IPB dan P3PT).

Iwan Setiawan, 2012. Agribisnis Kreatif. Penerbit Penebar Swadaya, Jakarta.

Kuncoro, M. 2006. Strategi Bagaimana Meraih Keunggulan Kompetitif. Penerbit Erlangga. Jakarta.

Lala M Kolopaking. 2002. Kemitraan dalam pengembangan usaha ekonomi skala kecil/ Gurem, makalah Lokakarya Nasional Pengembangan Ekonomi Daerah melalui Sinergi Pengembangan Kawasan. Jakarta. Hal 9.

Martin, J., F. Mayes, and Rodwell. 1983. Biokimia. EGC PenerbitBukuKedokteran. Jakarta Indonesia.

Mubyarto, 1991. PengantarEkonomiPertanian. LP3ES, Jakarta.

PT. Ichtiar Baru. 1988. Ensiklopedi Indonesia. PT. IchtiarBaru. Van Hoeve. Jakarta.

PengertianDefinisiarti- Inovasi, Http:// info dan tutorial. Blogspot.com/2012/04 .

Sutawi, 2002. ManajemenAgribisnis. Bayu Medu, UMM Press.

W. David Downey, Steven P. Erickson, 2004. ManajemenAgribisnis. PenerbitErlangga, Jakarta.

ZulianYamit, 2010. Manajemen Kualitas Produk dan Jasa. Penerbit EKONISIA, Yogyakarta. 


\section{MIMBAR Agribisnis ISSN 2460-432I \\ Volume 1・Nomor 1 • Juli 2015}

